\title{
New and interesting records of Drosophilidae (Diptera) from the Czech Republic and Slovakia
}

\author{
Jan Máca, Jindřich Roháček, Carlos Ribeiro Vilela \& Milena Březíková
}

\begin{abstract}
New and interesting records of Drosophilidae (Diptera) from the Czech Republic and Slovakia. - Acta Mus. Siles. Sci. Natur., 64: 101-106, 2015.

Abstract: Records of six species of the family Drosophilidae from the Czech Republic are presented. Drosophila tripunctata Loew, 1862, reported from the Old World long ago on the basis of a wrong determination, is newly confirmed from the region (Czech Republic: Bohemia); although this finding originates from a greenhouse, the record is important because this thermotolerant species has a potential to spread outdoors in Central Europe. Cacoxenus indagator Loew, 1858 is for the first time recorded from North Moravia (Czech Silesia) in the Czech Republic and Cacoxenus argyreator Frey, 1932 from Slovakia. Mycodrosophila poecilogastra (Loew, 1874) is new addition to the fauna of Bohemia, Drosophila (Sophophora) helvetica Burla, 1948 and Drosophila (Sophophora) suzukii (Matsumura, 1931) are new for Moravia.
\end{abstract}

Keywords: Faunistics, distribution, new records, Diptera, Drosophilidae, Czech Republic (Bohemia, Moravia), Slovakia.

\section{Introduction}

In the most recent electronic checklist of Drosophilidae of the Czech Republic and Slovakia (Máca 2009) a total of 75 species has been given from the Czech Republic (71 from Bohemia, 68 from Moravia) and 70 species from Slovakia. Meanwhile, altogether three additional species were recorded from the Czech Republic: Bohemia, viz. Caxoxenus (Paracacoxenus) argyreator Frey, 1932 and Scaptomyza (Scaptomyza) teinoptera Hackman, 1955 by Máca et al. (2013) and Drosophila (Sophophora) suzukii (Matsumura, 1931) by Březíková et al. (2014), so raising the number of species known from this country to 78 (in Bohemia to 74). In the present paper we supplement information about the regional fauna of Drosophilidae with further new records of representatives of this family from the Czech Republic and also from Slovakia.

\section{Material and methods}

The material examined is deposited in the collections abbreviated as follows: CISTA - Central Institute for Supervising and Testing in Agriculture, JMB - collection of Dr. Jan Máca, PhD. (České Budějovice, Czech Republic), MML - Municipal Museum, Mariánské Lázně (Czech Republic), MZSP - Museu de Zoologia, Universidade de São Paulo (São Paulo, Brazil), SMOC - Silesian Museum (Opava, Czech Republic).

Male genitalia were examined after detachment and dissection of the whole abdomen, and after examination all parts were transferred in glycerine into small coalesced plastic tubes and pinned below the respective specimens. This is indicated by the abbreviation "genit.prep." in the list of material examined.

A living specimen of $C$. argyreator was retained in a plastic tube to be subsequently photographed in a special glass box by means of a digital camera (Canon EOS 60D) with a macro lens (Canon MP-E 65 mm 1-5×) and ring macro flash (Canon MR-14EX).

Traditional subdivision of the genus Drosophila to subgenera is adopted, and Paracacoxenus is considered as a subgenus of Cacoxenus, in accordance with Brake \& Bächli (2008). The data on the geographical distribution of individual species are compiled from Bächli (2015), if not stated otherwise. 


\section{Results}

\section{Cacoxenus (s. str.) indagator Loew, 1858}

Material examined: CZECH REPUBLIC: N Moravia: Opava, Puškinova street 13, 4956'03"N, 17053'13"E, 265 m, on window in house, 9.5.2015, 1ㅇ, 12.5.2015, 1ㅇ․ J. Roháček leg. et det. (SMOC).

Distribution: The species is widespread in Europe but unrecorded from Fennoscandia; it is also known from Israel (Bächli et al. 2004: 332); its synonymy with C. cinctus (Rondani, 1856) from East Siberia (Spencer \& Martinez 1987) needs confirmation.

Comments: Although the type localities of $C$. indagator are Ingramsdorf (= Imbramowice) and Domanze (= Domanice) in the historical German (now Polish) Silesia, no records were known from the former Austrian Silesia (now Czech Silesia, being often treated as a northern part of Moravia, Czech Republic) till now. C. indagator is associated with mason bees (mainly Osmia spp., Apidae) and its larvae are known to develop, probably as commensals, in cells of their nests (Ashburner 1981). The above indoor records therefore indicate a nesting presence of Osmia bees in the close vicinity of the house.

\section{Cacoxenus (Paracacoxenus) argyreator Frey, 1932 (Figs 1, 2)}

Material examined: SLOVAKIA: Muránska planina NP, Pol'udnica res., Suchý dol, 4845'26"N, 2002'32"E, $480 \mathrm{~m}$, sweeping vegetation along brook and forest, 10.6.2014, 1ðึ, J. Roháček leg. et det. (SMOC).

Distribution: A Boreo-montane or Boreo-alpine species, hitherto only known from Fennoscandia (Finland, Norway, Sweden) and from the Swiss, German, Austrian and Italian Alps. Recently, it has also been recorded from the Czech Republic (Giant Mountains; Máca et al. 2013); however, a record from Poland (Nowakowski 1991), lacking concrete data, is doubtful.

Comments: This first record from Slovakia represents a new southeastern distribution limit of C. argyreator. Biology of this species remains largely unknown. In the Alps adults were collected in submontane to montane forested areas in canopy traps, in Scandinavia on fermented bait (Bächli et al. 2004). The above listed and photographed specimen (Figs 1, 2) was captured by netting around trunks of trees at a small brook in a submontane valley at a surprisingly low altitude (480 m).

\section{Drosophila (Sophophora) helvetica Burla, 1948}

Material examined: CZECH REPUBLIC: W. Bohemia: Hamrnický mokřad, Salicetum, 50.00N 12.68E, 19.4.-

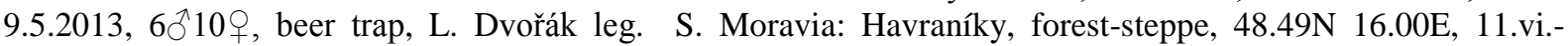
1.vii.2002, 330 m, 19, Malaise trap, M. Maixnerová leg.; all J. Máca det., coll. JMB.

Distribution: A widespread Palaearctic species, in Europe not known from its southeastern part.

Comments: Population density of $D$. helvetica is conspicuously uneven, both locally and temporally. In Switzerland it is the fifth most common drosophilid collected in baited traps, occurring rather at low elevations, although occasionally ascending up to $1000 \mathrm{~m}$ a. s. $\mathrm{l}$. (Burla \& Bächli 1985: 101). In the Czech Republic its occurrence is generally sporadic (Máca \& Laštovka 1985). The first record from Moravia and an additional record from Bohemia with relatively numerous specimens (considering the rarity of species in Czech collections) are given to supplement the knowledge of the distribution of $D$. helvetica in Central Europe.

\section{Drosophila (Sophophora) suzukii (Matsumura, 1931)}

Material examined: CZECH REPUBLIC: C. Moravia: Tučín, 49.27N 17.31E, 23.9.2015, 2 q, trap baited with apple vinegar in the garden, V. Koštálová leg. N. Moravia: Javorník, 50.39N 17.00E, 23.9.2015, $1 \delta^{\Uparrow} 1$, trap baited with apple vinegar in the garden, S. Kopecká leg.; all M. Březíková det., coll. CISTA. 

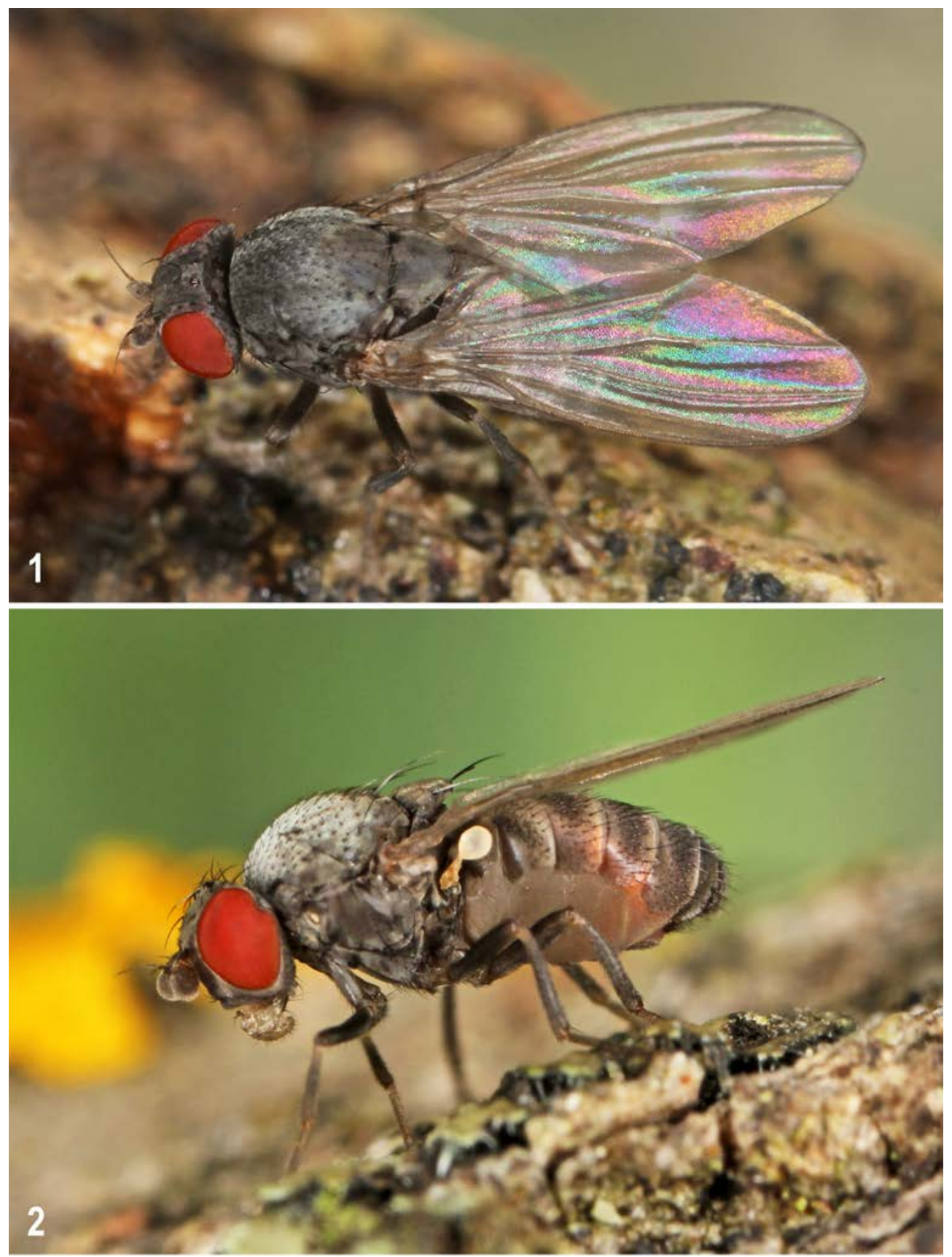

Figs 1-2: Cacoxenus (Paracacoxenus) argyreator Frey, 1932, a living male from the Muránska planina NP (Slovakia). 1 - dorsally, 2 - laterally. Body length ca. $2.8 \mathrm{~mm}$. Photos by J. Roháček.

Distribution: The species is widely distributed in the eastern part of Palaearctic Region and in some parts of Oriental Region, recently it has been introduced to North America, South America, Hawaii, Réunion and Europe.

Comments: It is a highly polyphagous and invasive pest, capable to cause significant damage to a number of cultivated berry and stone fruit crops in the Czech Republic. Drosophila suzukii ovoposits and feeds on healthy fruits, unlike most other Drosophila species. (Březíková et al. 2014). The first record from Moravia.

Drosophila (Drosophila) tripunctata Loew, 1862 (Figs 3, 4)

Material examined: CZECH REPUBLIC: C. Bohemia: Praha-Troja, botanical garden, greenhouse Fata Morgana 50.12N 14.41E, 12.-19.i.2012, 4ð11 , interception trap, all D. Ř́hová and J. A. Ponert leg; J. Máca 
det., C. R. Vilela confirmed; coll. MML (1ठำ), MZSP $\left(1 \delta^{\lambda} 1\right.$, male genit. prep.) and JMB (the remaining specimens).

Distribution: This species has hitherto only been recorded from the USA, Brazil and Colombia (Brake \& Bächli 2008).

Comments: First confirmed record in the Old World. Duda (1924) mentioned occurrence of "Spinulophila tripunctata Becker 1908, nicht = tripunctata Loew" in the Canary Islands and Sicilia, which, according to this and additional information, means that Becker (1908) misidentified the yet undescribed D. immigrans Sturtevant, 1921 as D. tripunctata Loew.

Regarding the above recent finding of D. tripunctata in Prague (= Praha), it is not known in which part of the greenhouse it was collected (the greenhouse consists of several parts with different temperatures and humidities). Nevertheless, D. tripunctata is considerably coldtolerant, as its distribution in the Nearctic Region extends as far to the north as Iowa and New Jersey in USA (Brake \& Bächli 2008). Considering this fact, the species thus also has a distinct potential to spread outdoors in Europe. Its larvae can develop in mushrooms and/or rotting vegetables (tomatoe, lettuce); strain-dependent preference for one of these breeding substrates occurs. Studying oviposition preferences, Jaenike \& Grimaldi (1983) demonstrated substantial potential of this species for evolutionary changes.
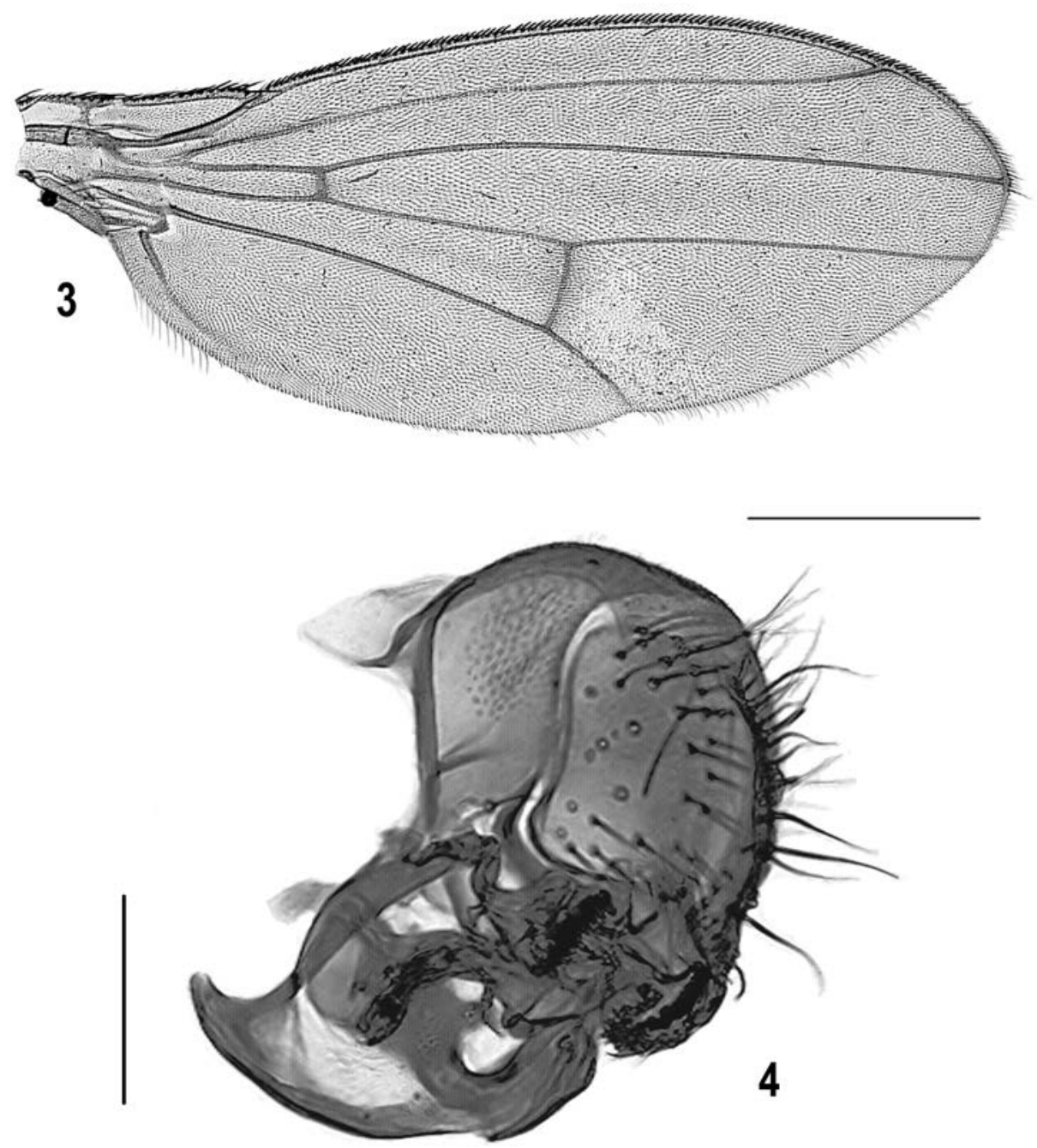

Figs 3-4: Drosophila (Drosophila) tripunctata Loew, 1862, male (Czech Republic). 3 - right wing, dorsal view (scale $0.5 \mathrm{~mm}$ ); 4 - whole male terminalia, oblique posterior view (scale $0.1 \mathrm{~mm}$ ). Photos by C. R. Vilela. 


\section{Mycodrosophila poecilogastra (Loew, 1874)}

Material examined: CZECH REPUBLIC: C. Bohemia: Žehuň, game preserve, on tree trunk, 50.16N 15.33E, 26.v.2012 1ठ̄, J. Máca leg. et det. (JMB).

Distribution: A Palaearctic species with rather scattered distribution, distributed just up to a little more north than $50^{\circ} \mathrm{N}$.

Comments: New species for the fauna of Bohemia. This record is not surprising because $M$. poecilogastra seems to have been spreading in the past ten years in Central Europe, now also occurring frequently in North Moravia and Silesia, see e. g. its recent occurrence on rotting giant Polypore fungus Meripilus giganteus in parks of the Opava city (Roháček \& Ševčík 2013).

\section{Discussion}

The fauna of Drosophilidae is comparatively well known in the Czech Republic and Slovakia. It is therefore surprising that several additional species have recently been added for the Czech Republic (Máca et al. 2013; Březíková et al. 2014; and above records) and also Slovakia (viz. C. argyreator above). The new faunal additions to these countries pertain to two groups: (1) exotic species recently introduced to Central Europe, viz. Drosophila suzukii and D. tripunctata and (2) Boreo-montane or Boreo-alpine species discovered in previously little investigated montane habitats (Cacoxenus argyreator, Scaptomyza teinoptera). With these new additions the Czech fauna of Drosophilidae now comprises 79 species and that of Slovakia 71 species. The comparison of these numbers indicate that Slovakia is obviously a little bit less explored country as to this family because the species richness is likely to be the same in both these areas. Therefore it can be expected with certainty that further drosophilid taxa will particularly be added to the fauna of Slovakia.

Acknowledgements: It is an agreeable duty to express our gratitude to Mgr. D. Ŕíhová and J. A. Ponert (Department of Invertebrate Zoology, Faculty of Science, Charles University, Praha, Czech Republic) for their organizing collection of insects in the Prague greenhouses and to Mr. L. Dvořák (Municipal Museum, Mariánské Lázně, Czech Republic) for the sorting of the material of Diptera from these collections, as well as for his own interesting findings. Mr. P. Chandler (Melksham, England) is thanked for all improvements and language corrections of the paper. The study of a junior author (J. Roháček) was financially supported by the Ministry of Culture of the Czech Republic by institutional financing of long-term conceptual development of the research institution (the Silesian Museum, MK000100595), internal grant of the Silesian Museum No. IGS201505/2015.

\section{References}

Ashburner M. (1981): Entomophagous and other bizarre Drosophilidae. Pp. 395-420. In: Ashburner M., Carson H.L. \& Thompson J.N. (eds): The genetics and biology of Drosophila. Vol. 3a, Academic Press, London.

Bächli G. (2015): TaxoDros, the database on taxonomy of Drosophilidae. http://taxodros.unizh.ch [Database 2015.03].

Bächli G., Vilela C.R., Andersson Escher S. \& Saura A. (2004): The Drosophilidae (Diptera) of Fennoscandia and Denmark. Fauna entomologica Scandinavica, Vol. 39, Brill, Leiden - Boston, 362 pp.

Becker T. (1908): Dipteren der Kanarischen Inseln. - Mitt. Zool. Mus. Berlin 4: 1-180.

Brake I. \& Bächli G. (2008). Drosophilidae (Diptera). World catalogue of insects. Vol. 9. Apollo Books, Stenstrup, $412 \mathrm{pp}$.

Březíková M., Dvořák L. \& Máca J. (2014): Faunistic records from the Czech Republic 367. Diptera: Drosophilidae. - Klapalekiana 50: 247-248.

Burla H. \& Bächli G. (1985): Diptera Drosophilidae. Insecta Helvetica 7. Schweizerische entomologische Gesellschaft, ETH-Zentrum, Zürich, 116 pp.

Duda O. (1924): Revision der europäischen Arten der Gattung Drosophila Fallén (Dipt.). - Entomol. Medd. 14: 246-313.

Jaenike J. \& Grimaldi D. 1983: Genetic variation for host preference within and among populations of Drosophila tripunctata. - Evolution 37: 1023-1033. 
Máca J. (2009): Drosophilidae Rondani, 1856. In Jedlička L., Kúdela M. \& Stloukalová V. (eds): Checklist of Diptera of the Czech Republic and Slovakia. Electronic version 2. http://www.edvis.sk/ diptera2009/families/drosophilidae.htm + CD-ROM: ISBN 978-80-969629-4-5.

Máca J. \& Laštovka P. (1985): Notes on the faunistics and zoogeography of the family Drosophilidae in Czechoslovakia. Pp. 273-287. In Pačuta M. \& Stollár Š. (eds): Organizmy a prostredie, Pedagog. fakulta, Nitra, 383 pp.

Máca J., Vaněk J. \& Barták M. (2013): Octomilkovití (Diptera, Drosophilidae), Camillidae (Dipt.), Campichoetidae (Dipt.), lužankovití (Dipt., Diastatidae) a nektarovkovití (Dipt., Odiniidae) české části Krkonoš. - Opera Corcont. 50: 171-184.

Nowakowski J.T. (1991): Braulidae - Curtonotidae. Pp. 224-228. In Razowski J. (ed.): Checklist of Animals of Poland. Vol. II. , Wydawnictwo Ossolineum, Wroclaw, Warszawa, Krakow, 342 pp.

Roháček J. \& Ševčík J. (2013): Diptera associated with sporocarps of Meripilus giganteus in an urban habitat. - Central European Journal of Biology 8(2): 143-167.

Spencer K.A. \& Martinez M. (1987): Additions and corrections to the Agromyzidae section of the Catalogue of Palaearctic Diptera (Papp, 1984). - Annls Soc. Entomol. Fr. (N. S.) 23: 253-271.

\section{Nové a zajímavé nálezy octomilkovitých (Diptera: Drosophilidae) z České republiky a Slovenska}

Jsou diskutovány nálezy šesti druhů čeledi Drosophilidae. Výskyt druhu Drosophila tripunctata Loew, 1862, uvedeného dříve ze Starého světa (Kanárské ostrovy, Sicílie) na základě chybné determinace, je nyní v Evropě (Čechy, Česká republika) potvrzen; přestože jde o sběr ze skleníku, lze důvodně očekávat, že tento termotolerantní druh se zde potenciálně může rozšírit i do volné přírody. Cacoxenus indagator Loew, 1858 je poprvé zaznamenán ze severní Moravy (české Slezsko) a Cacoxenus argyreator Frey, 1932 je poprvé uveden ze Slovenska. Druh Mycodrosophila poecilogastra (Loew, 1874) je nově zaznamenán z Čech, Drosophila helvetica Burla, 1948 a Drosophila suzukii (Matsumura, 1931) z Moravy.

Authors‘ addresses: Jan Máca, Czech Entomological Society, Viničná 7, CZ - 12000 Praha 2, Czech Republic; email: janxmaca@seznam.cz.

Jindřich Roháček, Slezské zemské muzeum, Nádražní okruh 31 CZ - 74601 Opava, Czech Republic; e-mail: rohacek@szm.cz.

Carlos Ribeiro Vilela, Departamento de Genética e Biologia Evolutiva, Instituto de Biociencias, Universidade de São Paulo, CxPostal 11464, São Paulo, SP 05422-970, Brazil; e-mail: crvilela@ib.usp.br.

Milena Březíková, Central Institute for Supervising and Testing in Agriculture, Division of Diagnostics, Šlechtitelů 23, CZ-779 00 Olomouc, Czech Republic;

e-mail: Milena.Brezikova@ukzuz.cz. 